\title{
Contributions of Latin America to scientific research in neuroscience and psychology
}

\author{
Alma Y. Galvez-Contreras ${ }^{1}$, Jorge Guzmán-Muñiz², Norma A. Moy-López², and Oscar Gonzalez-Perez ${ }^{2 *}$ \\ ${ }^{1}$ Neuroscience's Department, University Center for Health Science, Universidad de Guadalajara, Guadalajara, Jalisco; ${ }^{2} P$ sychology School, \\ Neuroscience's Laboratory, Universidad de Colima, Colima, Mexico
}

\begin{abstract}
Background: In Latin America, research in neuroscience and psychology has had a continuous development; however, the magnitude of this development and its impact on the comparison to other regions or countries has not been well studied. Objective: The objective of the study was to carry out a bibliometric analysis of scientific productivity in neuroscience and psychology in Latin America. Methods: We consulted the Scimago Journal and Country Rank database to obtain the classification of the Latin American countries in these knowledge disciplines, during the period from 2015 to 2020. Results: We found 32 Latin American countries with citable documents in these disciplines. Notably, 90\% of Latin American scientific productivity is concentrated in five countries: Brazil, Mexico, Argentina, Chile, and Colombia, with Brazil being the leading country in all cases. Conclusions: Research in neuroscience and psychology in Latin America has had a sustained and moderate growth. However, it is highly circumscribed in these five countries.
\end{abstract}

Keywords: Citations. H-index. Bibliometric indicators. Latin America. Neuroscience.

\section{Contribuciones de América Latina en investigación en el campo de las neurociencias y la psicología}

\section{Resumen}

Antecedentes: En América Latina, la investigación en neurociencias y psicología ha tenido un desarrollo continuo; sin embargo, hasta el momento la magnitud de dicho desarrollo y su impacto en comparación a otras regiones o países no ha sido bien estudiada. Objetivo: Realizar un análisis bibliométrico de la productividad científica en neurociencias y psicología en Latinoamérica. Material y métodos: Se consultó la base de datos Scimago Journal and Country Rank para obtener la clasificación de los países de Latinoamérica en estas disciplinas del conocimiento, durante el periodo comprendido del 2015 a 2020. Resultados: Encontramos 32 países latinoamericanos con documentos citables en estas disciplinas. Notablemente, el 90\% de la productividad científica latinoamericana está concentrada en cinco países: Brasil, México, Argentina, Chile y Colombia, siendo Brasil el país líder en todos casos. Conclusión: La investigación en neurociencias y psicología en América Latina ha tenido un crecimiento sostenido y moderado, pero ésta se encuentra muy circunscrita a estos cinco países.

Palabras clave: Citaciones. Índice h. Indicadores bibliométricos. América Latina. Neurociencias.

Correspondence:

*Oscar González-Pérez E-mail: osglez@ucol.mx DOI: 10.24875/RMN.21000034
Available online: 01-03-2022 Rev Mex Neuroci. 2022;23(2):44-50 www.revmexneurociencia.com 2604-6180 / @ 2021 Academia Mexicana de Neurología A.C. Published by Permanyer. This is an open access article under the CC BY-NC-ND license (http://creativecommons.org/licenses/by-nc-nd/4.0/). 


\section{Introduction}

Neurosciences are a group of scientific disciplines that study the structure, organization, and function of the nervous system. To achieve this aim, neuroscience includes disciplines such as psychology that provides knowledge about the human psyche and the functional biological systems. The importance of scientific research in neuroscience and psychology relies on providing knowledge to establish explanatory models of behavior and design strategies for clinical, educational, or social intervention ${ }^{1}$. Recently, in Latin America, research in these fields has had a sustained development $^{2}$; however, so far, the magnitude of said development and its impact on other regions or countries is unknown, which is a transcendental step to establish or modify policies to support and promote scientific research in any country. This type of information also provides each nation with a clear vision of the results and impact of its governmental efforts.

One of the mechanisms through which the scientific community can be provided with indicators of productivity, impact, and acceptance of new ideas by academic peers is by the analysis of international databases that provide quantitative information and allow compare countries or regions ${ }^{3}$. In particular, the SCImago Journal database includes the journals and world scientific indicators obtained from the information contained in the Scopus ${ }^{\circledR}$ database (Elsevier B.V.), the largest abstract and citation database of peer-reviewed literature worldwide. The SCImago Journal database is developed by non-profit and independent organizations: the Consejo Superior de Investigaciones Científicas, University of Granada, Extremadura, Carlos III (Madrid), and Alcalá de Henares ${ }^{4}$.

Likewise, within the SCImago Journal and Country Rank, database is the SCImago Journal Rank (SJR) index, which serves as a comparative reference of the productivity and impact of research in the various areas of knowledge developed by each country, which is updated annually during the months of April-June ${ }^{3,5}$. Thus, the aim of this work was to carry out a bibliometric analysis of the publications made in Latin America in the fields of neurosciences and psychology to know the state-of-the-art of the scientific development in Latin American countries.

\section{Methods}

A bibliometric analysis was carried out on the database SCImago Journal and Country Rank (http://www. scimagojr.com), which includes all the information contained in the Scopus ${ }^{\circledR}$ database, which is the largest abstract and citation database of peer-reviewed literature in the world 4 . Citation data were obtained from more than 34,100 titles from 5,000 international publishers and 239 countries worldwide 4 . The ranking of Latin American countries in two disciplines of knowledge was consulted: neuroscience and psychology. In both cases, the period analyzed ranged from 2015 to 2020. To avoid exclusions of scientific contributions in the field of psychology, we selected all the categories enlisted and pre-stabilized in the database, that is, applied psychology, clinical psychology, educational psychology, psychology of development, cognitive-experimental psychology, neuropsychology, physiological psychology, general psychology, and social psychology. In the field of neurosciences, all the sub-disciplines described in the database were selected without any exclusion: behavioral neuroscience, psychiatric neuroscience, cellular and molecular neuroscience, cognitive neuroscience, developmental neuroscience, autonomic and endocrine systems, neurology, general neuroscience, and sensory systems.

For both disciplines (psychology and neurosciences), data were extracted from all Latin American countries with scientific production ( $n=32$ countries), which were ordered in descending order according to the total number of documents published in 2020 (the most recent year documented). All these metrics were based on Scopus ${ }^{\circledR}$ database as of April 2021. The same criteria were taken into account to obtain the " $h$ " indexes for each country. For the analysis of the total number of citations, a search was carried out that included the past 5 years (2015-2020) of scientific productivity by country.

The analysis was based exclusively on citable documents, which included those texts submitted to rigorous arbitration by academic peers and, therefore, published in so-called refereed and indexed journals. In addition, the following parameters were included in the documentary analysis: the " $h$ " index, consisting of the total of citable documents published, the number of citations received, and the number of citations per document. The " $h$ " index quantifies both the scientific productivity and the scientific impact of a journal, a researcher or a country ${ }^{6}$. This represents the number of citations received for each article in descending order and is calculated by obtaining the number of articles $(h)$ of the journal that has received $h$ number of citations, that is:

$$
\text { h-index }(\mathrm{f})=\max _{i} \min (f(i), i)
$$


Where: " $f$ " is the function corresponding to the number of citations of each publication, while "i" corresponds to the maximum and minimum position of the citations received by each publication.

\section{Results \\ Research productivity in the field of psychology}

In the field of psychological research, we obtained records from 32 Latin American countries, which together published 4069 citable documents in 2020. It should be noted that the number of documents published in Latin America increased by approximately $30 \%$ in the course of the past 5 years. Notably, $86.3 \%$ of these texts were produced in five countries: Brazil, Mexico, Chile, Colombia, and Argentina (Table 1). Therefore, and for the purposes of simplifying the information, we decided to analyze in detail the productivity of these five countries during the past 5 years (2015-2020) (Figure 1A). The data suggest that the region's productivity is ascending. The Colombian case is the most notable, since in this period, its number of published documents increased by more than $200 \%$, going from 152 texts in 2015 to 358 texts in 2020.

Subsequently, we analyzed the number of citations obtained by these five countries (Figure 1B) and, in general, we observe a significant decrease in this item. However, the Brazilian case shows a very marked decline (approximately 13 times) in the number of citations received in 2019 (553 citations) compared to 2015 (7,424 citations). However, this country is experienced a significant improvement, reaching 1,776 citations in 2020. An exceptional case was Puerto Rico, which, during 2018, obtained a total of 429 citations that placed it very close to Argentina (511 citations), but in 2020, Puerto Rico showed a very pronounced drop ( 26 citations) and its productivity follows the same global behavior of the entire region. Finally, Colombia is the country with the highest ratio of citations per document (0.82), followed by Brazil (0.73), Chile (0.69), Mexico (0.55), and Argentina (0.54).

When analyzing the $\mathrm{h}$-index, we observed that Brazil was the country with the highest value in the entire region ( $h=126$ ) with a considerable advantage over its Latin American counterparts: Mexico $(h=82)$, Argentina $(h=73)$, Chile $(h=71)$, and Colombia $(h=63)$. However, this indicator is below the 10 most influential countries in this field: the United States $(h=863)$, the United Kingdom ( $h=474)$, Canada $(h=412)$, the
Table 1. Latin American productivity in the field of psychology in 2020. The table shows the total number of indexed (citable) publications for each country in decreasing order. Metrics based on Scopus ${ }^{\circledR}$ data as of April 2021

\begin{tabular}{|c|c|c|c|}
\hline Country & Documents & Citations & $h$-index \\
\hline Brazil & 1,776 & 1,352 & 126 \\
\hline Chile & 563 & 398 & 71 \\
\hline Mexico & 494 & 282 & 82 \\
\hline Colombia & 358 & 306 & 63 \\
\hline Argentina & 320 & 184 & 73 \\
\hline Peru & 154 & 102 & 45 \\
\hline Ecuador & 102 & 58 & 20 \\
\hline Uruguay & 55 & 38 & 29 \\
\hline Jamaica & 29 & 16 & 23 \\
\hline Puerto Rico & 27 & 26 & 58 \\
\hline Cuba & 24 & 31 & 32 \\
\hline Costa Rica & 23 & 18 & 35 \\
\hline Dominican Republic & 19 & 16 & 13 \\
\hline Paraguay & 15 & 11 & 7 \\
\hline Venezuela & 15 & 1 & 35 \\
\hline Trinidad and Tobago & 14 & 3 & 24 \\
\hline Bolivia & 12 & 2 & 20 \\
\hline Panama & 12 & 16 & 16 \\
\hline Guatemala & 10 & 5 & 15 \\
\hline Honduras & 8 & 3 & 6 \\
\hline Barbados & 8 & 0 & 13 \\
\hline Haiti & 8 & 4 & 11 \\
\hline Suriname & 6 & 6 & 4 \\
\hline El Salvador & 3 & 1 & 12 \\
\hline Grenada & 3 & 5 & 9 \\
\hline Guyana & 2 & 0 & 4 \\
\hline $\begin{array}{l}\text { Saint Vincent and the } \\
\text { Grenadines }\end{array}$ & 2 & 1 & 2 \\
\hline Nicaragua & 2 & 1 & 7 \\
\hline Bahamas & 1 & 0 & 8 \\
\hline Saint Lucia & 1 & 2 & 2 \\
\hline Antigua and Barbuda & 1 & 0 & 2 \\
\hline Guadeloupe & 1 & 1 & 5 \\
\hline Belize & 1 & 1 & 1 \\
\hline Total & 4,069 & 2,890 & ---- \\
\hline
\end{tabular}




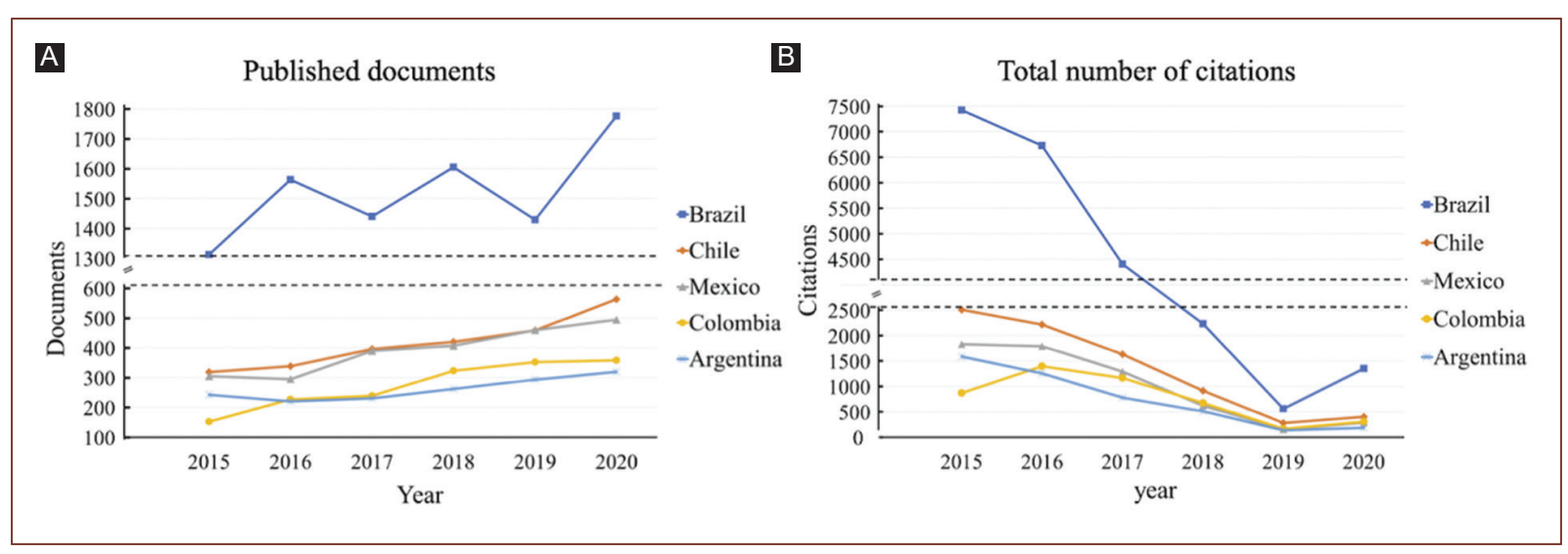

Figure 1. Scientific productivity in the field of psychology during the period from 2015 to 2020 . Total number of citable documents published during the last five years. A: total number of citations obtained by each country. B: in both cases, the graphs show data from the five most influential countries in this area.

Netherlands ( $h=358)$, Germany $(h=357)$, Australia $(h=305)$, Israel $(h=227)$, France $(h=227)$, Italy $(h=224)$, and Belgium $(h=217)$.

The average of citations per document in 2020 that Latin American countries received (0.62 citations per document) is approximately $40 \%$ the average of the 10 most influential countries in the field of psychology (1.04 citations per document). Taken together, these results indicate that Latin America, despite having relatively discrete $\mathrm{h}$-indexes, the average number of citations generated for each document did not show a significant lag compared to more developed countries.

\section{Research productivity in the neuroscience field}

In the field of neurosciences, the analysis revealed a record of 32 Latin American countries, which together published a total of 4,267 citable documents in 2020. The region's global productivity rose $30 \%$ over the course of 5 years. Once again, five countries stand out as they produced $90.4 \%$ of these texts: Brazil, Mexico, Argentina, Chile, and Colombia (Table 2). Again, to simplify the information, we analyzed in detail the productivity of these five countries during the past years 2015-2020 (Figure 2A). Two countries stand out with the highest growth rates: Colombia (215\%, from 115 documents in 2015 to 248 documents in 2020) and Chile (169\%, from 228 texts in 2015 to 387 texts in 2020).

Subsequently, we analyzed the number of annual citations obtained by these five countries (Figure 2B). Unfortunately, as in the field of psychology, the data obtained with neurosciences indicate that the five countries show a sustained decrease in the number of citations. Once again, Brazil showed a very important drop, going from 21,863 citations in 2015 to 1560 citations in 2019 (a drop of approximately 14 times). However, Brazil shows a partial recovery in 2020 when it reached 2071 citations. Of these five countries, Colombia is the country with the highest proportion of citations per document (1.38), followed by Brazil (1.27), Chile (1.25), Argentina (1.09), and Mexico (0.93).

The countries with the highest $h$-indexes are Brazil ( $h=206)$, Argentina $(h=146)$, Mexico $(h=134)$, Chile $(h=117)$, and Colombia $(h=80)$. Again, the comparison with more developed countries showed important differences in this indicator: the United States $(h=895)$, the United Kingdom ( $h=585)$, Germany ( $h=507$ ), Canada ( $h=465)$, France $(h=419)$, Italy $(h=383)$, the Netherlands ( $h=376)$, Japan $(h=365)$, Switzerland ( $h=358)$, and Australia $(h=333)$. However, it should be noted that the average number of citations per document in 2020 that the top 10 of Latin American countries received was 1.13 citations versus 1.515 average citations of the 10 most influential countries in the field of neuroscience. Taken together, these results indicate that Latin American productivity in neuroscience presents some difficulties, but its receptivity at the global level (manifested by the average number of citations) is quite acceptable and competes with that of countries with greater socioeconomic development.

\section{Discussion}

In this study, we analyzed productivity in the area of psychology and neurosciences in Latin America in the period from 2015 to 2020 (the most recently 
Table 2. Latin American productivity in the field of neurosciences in 2020. The table shows the total number of indexed (citable) publications for each country in decreasing order. Metrics based on Scopus ${ }^{\circledR}$ data as of April 2021

\begin{tabular}{|c|c|c|c|}
\hline Country & Documents & Citations & h-index \\
\hline Brazil & 2,071 & 2,894 & 206 \\
\hline Mexico & 724 & 701 & 134 \\
\hline Argentina & 426 & 504 & 146 \\
\hline Chile & 387 & 527 & 117 \\
\hline Colombia & 248 & 369 & 80 \\
\hline Peru & 65 & 79 & 41 \\
\hline Ecuador & 64 & 69 & 42 \\
\hline Uruguay & 51 & 65 & 64 \\
\hline Puerto Rico & 43 & 47 & 70 \\
\hline Cuba & 41 & 46 & 69 \\
\hline Grenada & 25 & 22 & 19 \\
\hline Venezuela & 21 & 54 & 63 \\
\hline Panama & 18 & 28 & 41 \\
\hline Costa Rica & 18 & 41 & 44 \\
\hline Dominican Republic & 9 & 0 & 11 \\
\hline Trinidad and Tobago & 8 & 5 & 17 \\
\hline Bolivia & 6 & 40 & 18 \\
\hline Guatemala & 5 & 5 & 12 \\
\hline Jamaica & 5 & 1 & 19 \\
\hline Martinique & 4 & 0 & 16 \\
\hline Guyana & 3 & 6 & 4 \\
\hline French Guiana & 3 & 7 & 6 \\
\hline Antigua and Barbuda & 3 & 1 & 6 \\
\hline Honduras & 3 & 40 & 14 \\
\hline Saint Kitts and Nevis & 3 & 3 & 8 \\
\hline Paraguay & 3 & 1 & 12 \\
\hline Barbados & 2 & 1 & 15 \\
\hline Nicaragua & 2 & 0 & 5 \\
\hline Suriname & 1 & 11 & 10 \\
\hline Cayman Islands & 1 & 0 & 5 \\
\hline Dominica & 1 & 0 & 10 \\
\hline Bahamas & 1 & 0 & 2 \\
\hline El Salvador & 1 & 1 & 7 \\
\hline Guadeloupe & 1 & 0 & 15 \\
\hline Total & 4,267 & 5,568 & ------ \\
\hline
\end{tabular}

documented year). Our data indicated that $90 \%$ of scientific production in Latin America, both in both disciplines, is concentrated in these five countries: Brazil, Mexico, Argentina, Chile, and Colombia, which have the highest number of products and h-indexes.

The Brazilian phenomenon is remarkable since, in the first decade of the $21^{\text {st }}$ century, Brazil increased its investment in research by $1.13 \%$ of its Gross Domestic Product (GDP) ${ }^{7}$. This number contrasts sharply with the rest of the Latin American countries that lead our list. Argentina allocates only $0.6 \%$, Mexico $0.504 \%$, Chile $0.335 \%$, and Colombia $0.3 \%$ of its GDP for research (Source: OECD Science 2020, Technology and R and D Statistics: Main Science and Technology Indicators), which would explain the difference in the productivity of Brazilians in these areas. Brazilian leadership seems to have exploded since 2006, this country structured aggressive investment policies for research with mixed participation, where governmental funds (direct financing and fiscal stimuli) and money from private initiative (industry and private universities) were involved, being the private funding the most significant contribution, which allowed Brazil to reach its highest point in 2010?. For the area of psychology in 2006, Brazil had a total of 354 citable articles while Mexico (the second country in productivity), only had a total of 59 documents ${ }^{2}$. However, it should be noted that from 2016 to the end of 2019, Brazil has suffered a sustained decline in government contribution to research, which has been progressively reduced to levels of $42 \%$ in 2019 compared to $2010^{8}$ (Source: National Science, Technology, and Innovation Indicators Brazil 2018), which may explain the dramatic drop in productivity during the past 5 years. Remarkably, the Brazilian downtrend seems to reverse in 2020 in both psychological sciences and neurosciences. Some authors have attributed the significant rebound of Brazil in all scientific disciplines to the role of governmental and academic Brazilian institutions to promote and facilitate scientific collaborations with some foreign partners, generating the opportunity of Brazilian researchers access to financing from international agencies ${ }^{9}$. Brazil finances primarily mobility for doctoral stays or visiting professors, rather than financing for research projects ${ }^{9}$. This type of financing has helped Brazilian students and researchers to establish high-quality collaborative work with multidisciplinary groups around the world.

A similar case was observed in Chile, which in the period from 2005 to 2008 was the country with the highest global scientific production in Latin America, but some changes in public policies to support 

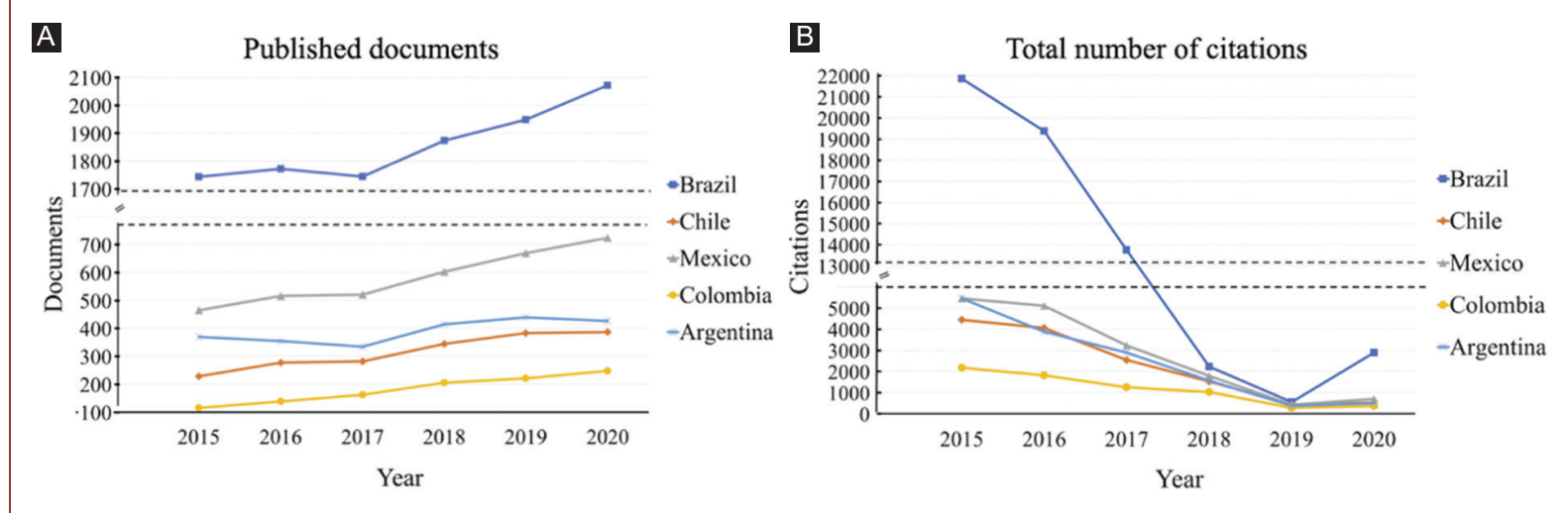

Figure 2. Scientific productivity in the field of neurosciences during the period from 2015 to 2020 . Total number of citable documents published during the analyzed period. A: total number of citations obtained by each country. B: in both cases, the graphs show the data for the five countries with the highest productivity in this area.

research and the economic crisis of 2009 strongly affected their scientific performance ${ }^{2}$. In contrast, Colombia shows a discreet but constant increase in its scientific productivity that may be the result of a series of policies implemented since 2006, such as promotion of national and international collaborations through the generation of related work groups ${ }^{10}$, as well as the incorporation of Colombian journals indexed in the Web of Science ${ }^{2}$, which has favored the publication and visibility of their work. In summary, the lag in Latin American research with respect to other countries could be explained by diverse reasons, such as incipient research areas, low level of investment in research, insufficient political participation of researchers in funding agencies, lack of infrastructure, little specialized postgraduate training, and low overall budget ${ }^{11}$.

In our study, we found that Colombia and Chile are the countries with the highest ratios in the number of citations per published article than the rest of the countries analyzed. In contrast, Mexico is the country with the lowest ratios in both scientific fields. This measurement is considered by some authors as an indirect indicator of the relevance of its scientific productivity ${ }^{12}$. Yet, the number of citations and the ratios by themselves is not sufficient indicators to measure the quality of scientific research of an individual or country. For this reason, the Hirsch index (h-index) is used as an indispensable indicator to assess the impact of the research generated ${ }^{13}$. However, some authors indicate that this index is susceptible to being modified by self-citations and cannot determine the prestige of the publications ${ }^{14,15}$. Nevertheless, the $\mathrm{h}$-index has become popular as a good quality indicator since it has considerable predictive power and allows us to analyze a bibliometric trajectory in the long term ${ }^{6,16}$. We observed that the three countries with the highest $h$-indexes in the area of neuroscience are Brazil, Argentina, and Mexico, which indicate the trajectory degree of these nations in this field. Regarding the field of psychology, Brazilian h-index confirms it as the leading nation in Latin America, well above Mexico and Argentina. This as a whole suggests that the works generated in Brazil, Mexico, and Argentina is those with the greatest visibility and acceptance by their scientific-academic peers. Although to measure the real impact of Latin American research, it would also be necessary to analyze the impact factor of each of the journals where its researchers publish their findings.

However, the growth observed in Latin America, the speed of development and the numerical indicators are still far from countries with greater socioeconomic development (the United States, the United Kingdom, Germany, or Canada). A plausible explanation for this phenomenon, in addition to the availability of economic resources, is the implementation of Latin American public policies, which tend to give priority to funding research focused on solving social and health problems that afflict them ${ }^{17-19}$. Another possible explanation is that researchers or funding companies prefer to patent their findings and seek economic benefit in the short term instead of publishing them in scientific journals ${ }^{14}$. Despite the socioeconomic development seems to be the most important challenge for all Latin American countries, all these countries must take actions to close the gap with more development economies. One of the most successful strategies to trigger the 
development of science in more challenged countries is the international collaboration ${ }^{20,21}$. This approach increases the level of scientific rigor, makes more efficient the scientific infrastructure, advances the scientific efforts, and helps improve language and writing skills.

\section{Conclusions}

Five countries lead research in the areas of neuroscience and psychology: Brazil, Mexico, Argentina, Chile, and Colombia, with Brazil being the country that leads both disciplines and Colombia the one that shows the fastest growth. Despite the difficulties, the global receptivity of Latin American research is acceptable and competes with that of countries with greater socioeconomic development.

\section{Funding}

This research has not received any specific grant from public, commercial, or non-profit sector agencies.

\section{Conflicts of interest}

The authors declare that they have no conflicts of interest.

\section{Ethical disclosures}

Protection of human and animal subjects. The authors declare that no experiments were performed on humans or animals for this study.

Confidentiality of data. The authors declare that no patient data appear in this article.

Right to privacy and informed consent. The authors declare that no patient data appear in this article.

\section{References}

1. Shriver AJ. The role of neuroscience in precise, precautionary, and probabilistic accounts of sentience. In: Johnson LS, Fenton A, Shriver A, editors. Neuroethics and Nonhuman Animals, Advances in Neuroethics. Switzerland: Springer Nature Switzerland AG; 2020. p. 221-33.

2. Vera-Villarroel P, Lillo S, López-López W, Silva LM. La producción científica en psicología latinoamericana: un análisis de la investigación por países. Rev Latinoam Psicol. 2011;43:95-104.

3. Valderrama-Zurián JC, Castelló-Cogollos L, Aleixandre-Benavent R. Trends in scientific research in Insights into Imaging: a bibliometric review. Insights Imaging. 2019;10:79.

4. SCImago. SJR-SCImago Journal and Country Rank. Available from: http://www.scimagojr.com.

5. Abraham J. National culture as a correlate of research output and impact [version 3; peer review: 2 approved with reservations]. F1000Res. 2019;8:1-22

6. Hirsch J. An index to quantify an individual's scientific research output. PNAS. 2005;102:16569-72.

7. Pinheiro-Machado R, de Oliveira PL. The Brazilian investment in science and technology. Braz J Med Biol Res. 2001;34:1521-30.

8. Escobar H. Brazilian scientists lament "freeze" on research budget Science. 2019;364:111.

9. McManus C, Baeta Neves AA, Maranhão AQ, Souza Filho AG, Santana JM. International collaboration in Brazilian science: financing and impact. Scientometrics. 2020;125:2745-72.

10. Enríquez Martínez Á, Castañeda ZD. Estado actual de la investigación en psicología organizacional y del trabajo en Colombia. Acta Colomb Psicol. 2006;9:77-86.

11. Robayo-Castro B, Rico JL, Hurtado-Parrado C, Ortega LA. Impacto y calidad de la productividad académica de los investigadores en Colombia en neurociencia comportamental utilizando modelos animales. Univ Psychol. 2016;15:15.

12. Ioannidis JP, Klavans R, Boyack KW. Multiple citation indicators and their composite across scientific disciplines. PLoS Biol. 2016;14:1-17.

13. Fargen RM. Bibliometric indices: defining academic productivity and citation rates of researchers, departments and journals. BMJ J. 2017:10:102-6.

14. Buela-Casal G. Evaluación de la calidad de los artículos y de las revistas científicas: propuesta del factor de impacto ponderado y de un índice de calidad. Psicothema. 2003;15:23-35.

15. Bornman Lutz DH. The state of $h$ index research. EMBO Rep. 2009;10:2-6.

16. Hirsch JE. Does the $\mathrm{h}$ index have predictive power? Proc Natl Acad Sci U S A. 2007;104:19193-8.

17. Gallegos $M$, Berra $M$, Benito $E$, López $W L$. Las nuevas dinámicas del conocimiento científico y su impacto en la psicología latinoamericana. Psicoperspectivas. 2014;13:106-17.

18. Ezequiel B. Evaluación del impacto social de la investigación en Psicologia. Datos preliminares. In: Evaluación Del Impacto Social de la Investigación en Psicología Datos Preliminares III Congreso Internacional de Investigación y Práctica Profesional en Psicología XVIII Jornadas de Investigación Séptimo Encuentro de Investigadores en Psicología del MER. Buenos Aires, Argentina: Universidad de Buenos Aires; 2011. p. 387.

19. Dorta Contreras AJ, Arencibia Jorge R, Martí Lahera Y, Araújo Ruiz JA Indicadores basados en análisis de citas para la caracterización de las neurociencias cubanas. Acimed. 2008;18:1-21.

20. McManus CM, Baeta Neves AA, Maranhão AQ. Brazilian publication profiles: where and how Brazilian authors publish. Ann Acad Bras Cienc. 2020;92:1-22.

21. Hossain NM. Current status of global research on novel coronavirus disease (COVID-19): a bibliometric analysis and knowledge mapping. F100Res. 2020;9:374. 